The $B D J$ News section accepts items that include general news, latest research and diary events that interest our readers.

Press releases or articles may be edited, and should include a colour photograph if possible. Please direct your correspondence to the News Editor, Arveen Bajaj at the BDJ, The Macmillan Building, 4 Crinan Street, London N1 9XW or by email to bdj@bda.org

\section{Student award launched}

Wrigley Oral Healthcare in Action (OHA) is giving all dental students the chance to win $£ 1,000$ for creating a patient information resource to promote a better

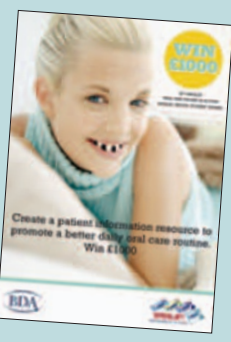
daily oral routine.

The Student Award, which is open to dental and hygiene students throughout the country, gives students the opportunity to put their knowledge of oral care into practice helping their patient's daily oral healthcare routine.

The aim of the resource is to communicate a better oral routine for patients aged 18-35 years. The key oral health messages need to be included, such as brushing, regular check ups and chewing sugar free gum.

The winning student will receive a cash prize of $£ 1,000$ and will be invited to attend the British Dental Association Conference in May 2007 where they will be awarded with a certificate.

Students can ask their tutor for an entry form or request one via email at wrigleyoha@ideaslondon.com. Students will be judged on creativity, technical accuracy and appeal to the target age group.

\section{Entrepreneur honoured}

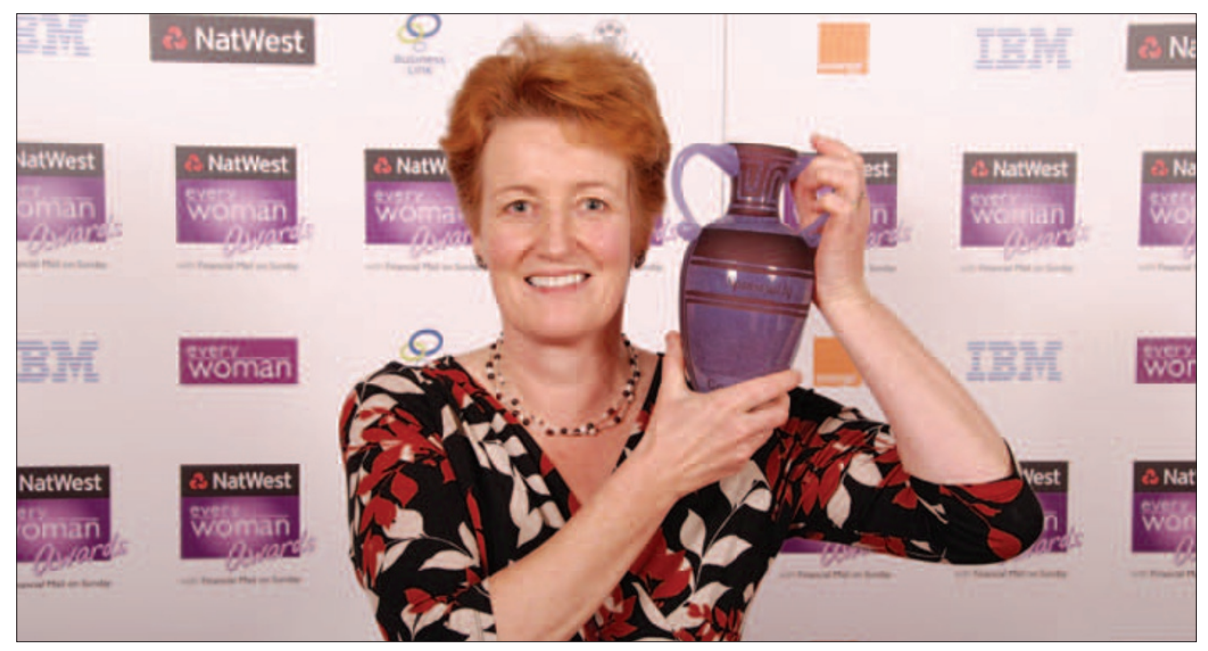

Dr Wendy Sandeman, founder of Wendy Sandeman Dental has won the NatWest everywoman Hera Award for outstanding entrepreneurial success by a woman aged 50 and over. Founded in 2003 by everywoman, an organisation for women in business, the awards recognise and celebrate Britain's most inspiring female business owners.

Dr Sandeman was honoured with the Hera award at a ceremony hosted by BBC presenter, Fiona Bruce, and attended by awards patron Lady Lynn Forester de Rothschild along with some $\mathbf{3 0 0}$ women of achievement, including pioneering women from industry, female entrepreneurs and representatives from government.

The awards ceremony was followed by a reception at the House of Commons. According to the organisation, each everywoman award is named after ancient Greek goddesses, feminine archetypes of courage, determination, perseverance, wisdom and strength.

Dr Sandeman began her practice with the aim of providing a calm and holistic dental experience, banishing memories of painful check ups to the past. In addition to high quality dental care, she is dedicated to offering luxuries that help relax patients and allow them to enjoy their treatment. Warm hand waxes and DVDs are provided during longer treatments. The practice also offers a small bar and in the summer refreshments are served outside in the garden. Dr Sandeman's idea for the practice evolved from patient experience: "More and more patients were coming to me because they felt they weren't listened to. People like to be aware of all the options and be able to make the choice themselves. If they come for dental care and are pampered in pleasant surroundings they leave feeling good".

\section{Essay prize launched}

The Association of British Academic Oral \& Maxillofacial Surgeons has announced a new undergraduate essay prize to be awarded to the best essay with the title of "Discuss the future of surgical endodontics in the light of predictable osseointegrated dental implants".
It is open to all undergraduate dental students registered during the academic year 2006-2007. The essay should be up to 3,500 words, double-spaced and word processed. It should be submitted electronically (preferably by e-mail) to the honorary secretary of the asso- ciation (Dr Richard Oliver at richard. j.oliver@manchester.ac.uk). The essay will be marked independently and blindly by two assessors after being anonymised by the secretary.

The closing date is 30th September 2007. 


\section{Oral health charity Dentaid targeted by thieves}

The oral health charity Dentaid has suffered a major setback following the theft of over half its stock of instruments, destined for charitable projects in the developing world. Despite CCTV and an alarm, thieves broke into the charity's instrument stores late at night last month and stole 21 crates of sorted instruments.

The new and second-hand instruments have almost certainly been stolen for their scrap metal value, following a spate of similar thefts from local businesses in the Salisbury region.

The charity says that whilst the scrap value of these instruments may yield $£ 100$ at most from a scrap merchant, for Dentaid to replace these specialist instruments would cost well over $£ 50,000$ - a cost the charity cannot afford. Unfortunately, none of the instruments were insured as the massive new for old replacement value of all Dentaid's donated stocks would lead to prohibitive insurance premiums.

Mike Phillips, Dentaid's volunteer instrument coordinator said, "This is a real blow. Last year we supplied instrument kits to dozens of charitable dental projects in Romania, Nepal, India, Zambia, Uganda, Burkina Faso, Somalia, Kenya, The Gambia, Ukraine, Peru, Liberia, China, Sri Lanka and Nicaragua. But following this theft we are desperately short

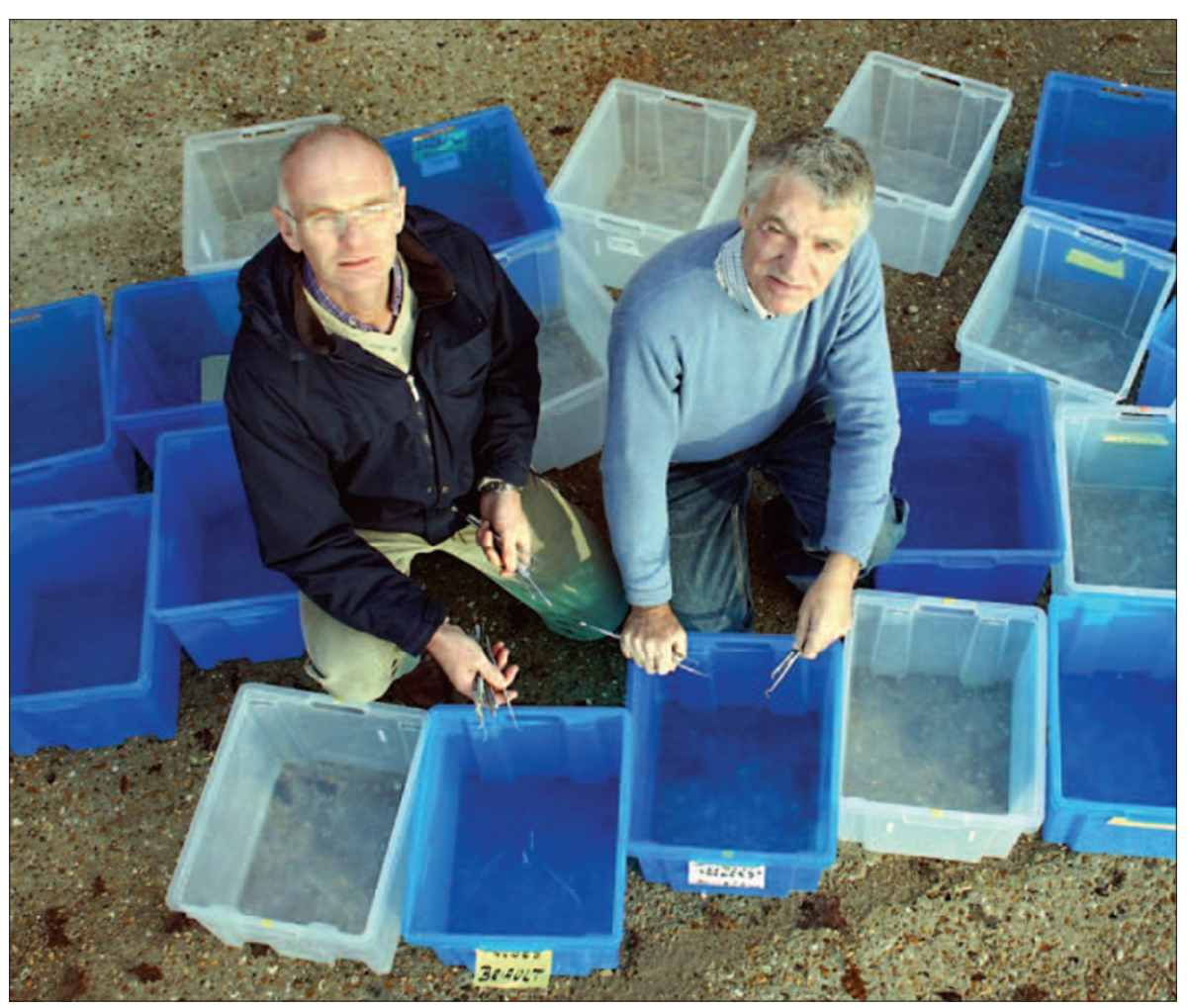

\section{Funding received for biodegradable implant research}

of certain items and within a few months will exhaust our remaining stock. Further projects are in serious jeopardy. The idea that all these instruments have been stolen to be sold for £50 scrap value is heartbreaking."

Dentaid desperately needs to build up its instrument stocks again and is appealing to dentists who have any dental instruments they no longer require, to please send them to Dentaid at Giles Lane, Landford, Salisbury SP5 2BG. Following the theft, the charity is particularly short of mirrors, luxators, elevators (Lindo Leviens, Warwick James, Cryers) and forceps, but all instruments would be gratefully received. The charity is also going to need to invest in new physical security to protect its premises further from these type of thefts and potentially buy new instruments to replace those stolen, drawing on financial resources currently budgeted to other projects. If you, your practice or your company would like to contribute financially to either of these causes, please send a cheque to Dentaid at the above address or give online through Dentaid's website at www.dentaid.org. In the unlikely event that an attempt is made to sell the stolen items to practitioners, please get in contact with Dentaid so that the police can be alerted.

\section{A PhD student from UCL Eastman} Dental Institute has been awarded the Dorothy Hodgkin Postgraduate Award to investigate new biodegradable drug-releasing adhesives and implants.

Ms Xin Zhao's work will involve multidisciplinary studies of a novel family of materials that are currently being patented through UCL Biomedica for a range of biomedical applications.

The work involving new material synthesis and mechanical and biological studies will be supervised by Drs Anne Young and Vehid Salih of the Division of Biomaterials \& Tissue Engineering.

It is planned that optimised materials produced in the project will additionally be supplied for a number of other projects around the world including steriolithography experiments (Russia) and antibacterial investigations (South Africa) in addition to Departments at the Eastman, Imperial and Kings.

The Dorothy Hodgkin Postgraduate Award enables talented students from India, China, Hong Kong, South Africa, Brazil, Russia and the developing world to study for a PhD in leading UK research institutions.

At present, 26 Higher Education Institutions have received around 80 awards, with UCL receiving a total of six. These fully-funded awards are open to students of science, engineering, medicine, social sciences and technology.

Award-holders have the additional benefit of being able to apply for a Home Office scheme that allows foreign nationals who have studied maths, science or engineering in the UK to remain and work in this country for a year after graduation.

When students return home, they will help to provide the scientific expertise needed to tackle issues such as establishing supplies of clean water and secure energy, and to help combat diseases such as HIV/AIDS and malaria.

The scheme will also help to promote scientific and commercial collaboration between the UK and participating countries. 


\section{Israeli-Palestinian partnership in dentistry}

Dentistry has been at the heart of a breakthrough in cooperation between Israeli and Palestinian academics during the first Middle East Symposium on Dental Medicine.

The symposium, focusing on dental implants, was held this winter under the auspices of the Dr Walter Cohen, DDS, Middle East Center for Dental Education of the Hebrew University-Hadassah School of Dental Medicine in Jerusalem despite the existing tense political situation. The symposium is a further expression of the budding relationship that has been launched between the Hebrew University of Jerusalem and Al-Quds University, involving in particular the Hebrew University-Hadassah School of Dental Medicine and the Al-Quds University Faculty of Dentistry, the first Palestinian school of dental medicine.

Under a new agreement between the two schools, significant contacts involving collaboration between senior academics and students in research as well as in teaching and clinical work are being implemented. Collaborating in the symposium were Case Western Reserve, Drexel and Harvard Universities and the University of Pennsylvania in the US and Hacettepe University in Turkey. Leading multi-national companies in dental equipment supplies provided $\$ 90,000$ in financial support for the event. Internationally known academic figures in dental treatment and research from the US, Turkey, France, Israel and the Palestinian Authority presented papers at the symposium.

"We can build bridges at the level of professions and live in peace as human beings. We must be a model for others,"

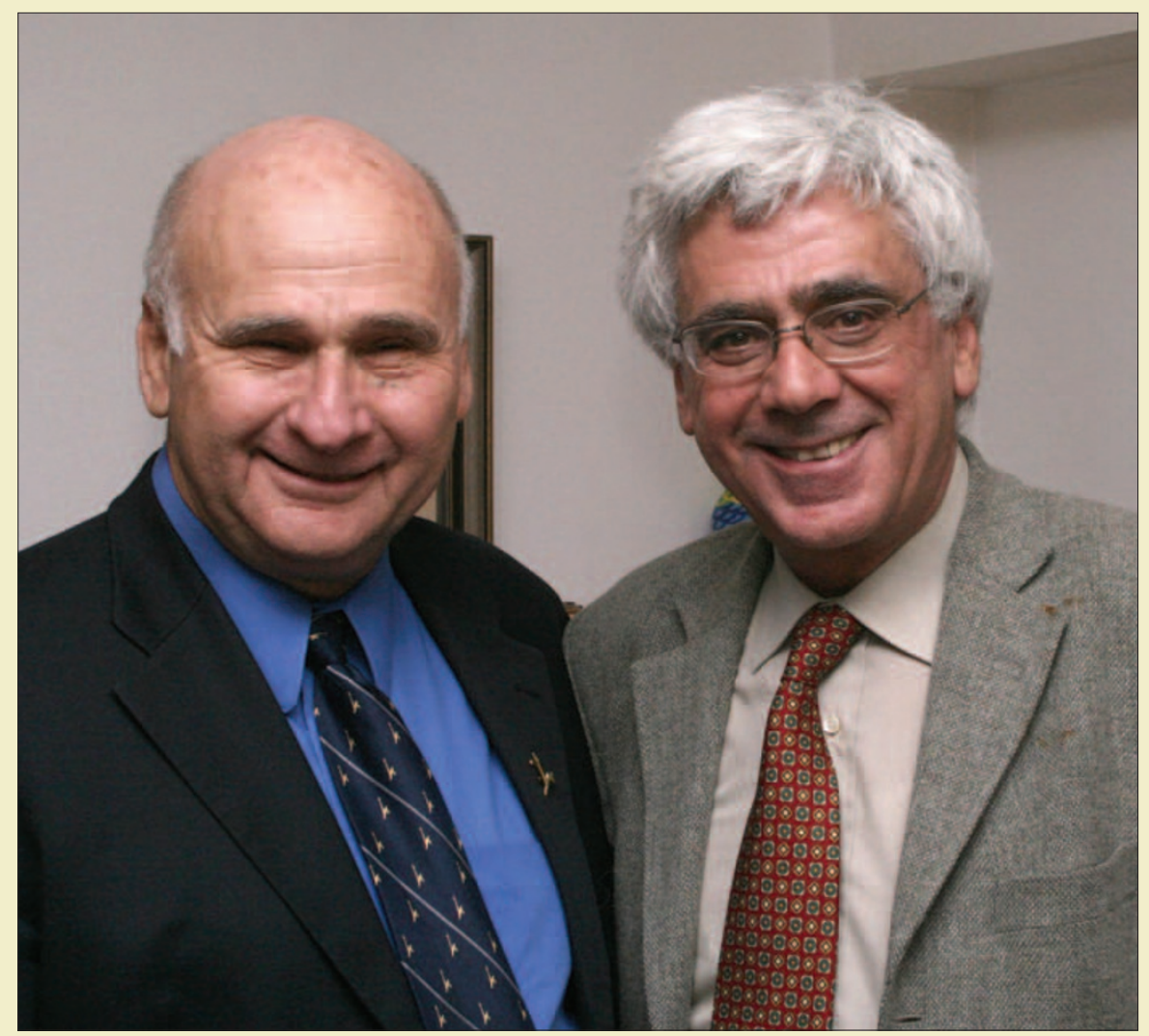

Professor Menachem Magidor (left), President of the Hebrew University, and Professor Sari Nusseibeh, President of Al-Quds University at the joint Hebrew University Al-Quds University dental symposium. Photo courtesy of Chezi Hojesta.

stated Professor Adam Stabholz, Dean of the Hebrew University-Hadassah School of Dental Medicine, and Professor Musa Bajali, Dean of the Al-Quds Faculty of Dentistry. "As dentists, we know that occasionally a bridge may fail due to a diseased abutment. The decayed abutments of the previous bridges will be replaced by the implants we shall place, guided in their placement by our belief in the ability to work together."
According to the institutions, the programme is a further expression of the joint statement issued last year in London by the presidents of the Hebrew University and Al-Quds University, Professor Menachem Magidor and Professor Sari Nusseibeh, respectively, for continuing efforts "to work together in the pursuit of knowledge for the benefit of our peoples" and to oppose academic boycotts or discrimination.

\section{Dental materials prize-winner}

A second year undergraduate from Queen Mary University of London recently won the Advanced Healthcare Ltd (AHL) Best Dental Materials Student of the year award by achieving first class results in his first year.

Sean Prem won the award at QMUL's annual Department of Materials combined Industrial Liaison Event and Prize Day which took place recently at the University's Mile End campus.

The AHL Best Dental Materials prize includes a $£ 500$ cheque and it was pre- sented to Sean by David Moore, AHL's general manager. James Busfield, Deputy Head of the Materials Department at the University, said Sean was the best dental materials student this year by far.

In addition to the prize giving, the Industrial Liaison Event included a post-graduate research poster session featuring around 60 materials-based posters, a facilities tour and a meeting of the University's Industrial Advisory Board.

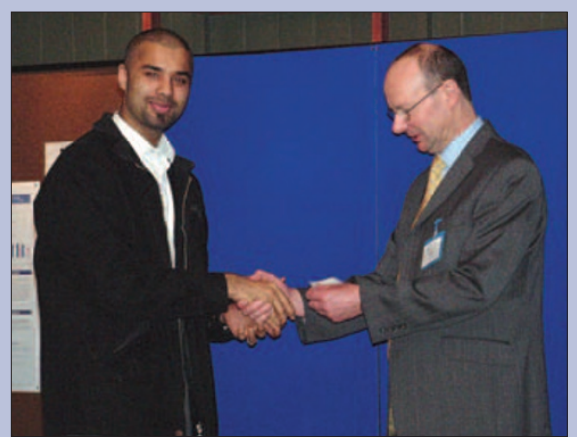

Sean Prem receiving his award. 


\section{DIARY}

January

\section{5th Annual North American}

Orthodontic Conference for Full

Face Orthodontic Study Group

Date: 19-21 January 2007

Venue: New Orleans, USA

Tel/Fax: (888) 891-6485

Setting up in practice

Date: 19 January 2007

Venue: BDA Lecture theatre

Tel: 02075634590

Email: events@bda.org

February

2007 Career opportunities in UK Date: 9 February 2007

Venue: Hotel Russell, Russell Square, London

Tel: 02075634590

Email: events@bda.org

Moving to private practice

- conversion and beyond

Date: 23 February 2007

Venue: BDA, London

Tel: 02075634590

Email: events@bda.org

April

The Society of Manchester Dental Alumni (SOMANDA) biennial meeting and reunion

Date: 20 April 2007

Venue: University of Manchester

Email: carolynstylianou@ntlworld.com

May

\section{ADI 20th Anniversary Congress}

Date: 3-5 May 2007

Venue: ICC in Birmingham

www.adi.org.uk

\section{BDA British Dental Conference}

and Exhibition 2007

Date: 24-26 May 2007

Venue: Harrogate International

Centre (HIC)

Tel: 02075634590

Email: events@bda.org

\section{Experts confirm the benefits of fluoride for dental health}

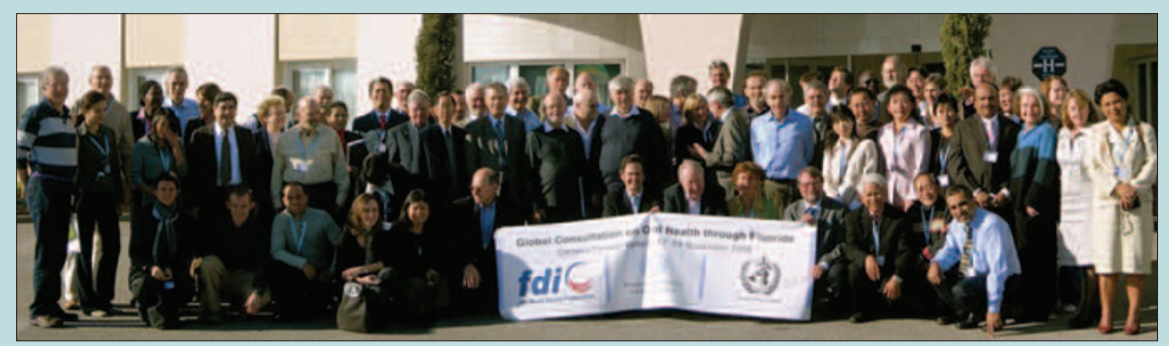

The consultation group in Geneva.

A panel of experts on fluoride has urged governments and other influential bodies to develop effective legislation, necessary directives and programmes to ensure access to fluoride for dental health in all countries.

Eighty experts from thirty countries gathered for a Global Consultation on Oral Health through Fluoride, jointly convened by the World Health Organization (WHO), FDI World Dental Federation and the International Association for Dental Research recently in Geneva and expressed their deep concern about growing disparities in dental health and the lack of progress in tackling the worldwide burden of dental caries, particularly in disadvantaged populations.

The experts recommended developing effective legislation, necessary directives and programmes to ensure access to fluoride for dental health in all countries, include fluoride in health communications, health promotion strategies and programmes, include fluoride for dental health when promoting health through healthy diets, to encourage governments to reduce or remove taxation and tariffs on fluoride products for dental health and to encourage suppliers to improve availability of effective affordable fluoride toothpaste.

"The benefits of fluoride for the prevention and control of dental caries have been known to the scientific and public health community for more than 60 years. While fluoride in various delivery systems is widely available in many developed countries, it is estimated that globally only 20 percent of the world's population benefit from appropriate exposure to fluoride," said Dr Poul Erik Petersen, Chief of the Oral Health Unit at WHO. "Regrettably, particularly people living in developing countries and disadvantaged communities are deprived of fluoride for dental health."

The adopted declaration will guide the work of the alliance and various international action groups that were established during the consultation. The full text of the declaration is available at www.fdiworldental.org/public health/3_7fluoride.html.

\section{New appointment}

Hugh Smith has been appointed new head of the Dental Complaints Service, which helps resolve complaints about private dental care. Mr Smith spent 21 years with Barclays Bank, including four years in Botswana in the mid-1990s. He joined Barclays from the army, in which he spent four years after leaving the University of St Andrews. Mr Smith replaces Gordon Miles, who was recently appointed as Director of Resources and Planning at the General Dental Council.

The Dental Complaints Service was launched last May, with the aim of helping to restore the relationship between the patient and the dental professional. By November, it had received more than 3,500

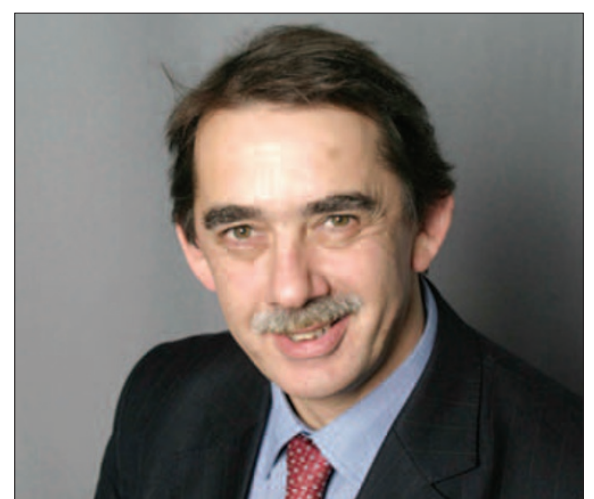

calls on its 08456120540 complaints hotline, and more than 800 complaints. Nearly half (42 per cent) were closed in a single working day, and nearly three-quarters (74 per cent) were closed in two days. 